Research Journal of Pharmacology and Pharmacy
(ISSN:2572-8377)

\title{
Evaluation of the Antioxidant Potential of Artisanal Liqueurs Produced From Fruits of the Caatinga Biome
}

João Victor de Oliveira Alves ${ }^{1 *}$, Francisco Henrique da Silva1, João Carlos de Oliveira Pinto', Janderson Weydson Lopes Menezes da Silva², Paloma Maria da Silva ${ }^{1}$, Irivânia Fidelis da Silva Aguiar ${ }^{1}$, Katharina Marques Diniz ${ }^{1}$, Fálba Bernadete Ramos dos Anjos ${ }^{3}$, Márcia Vanusa da Silva ${ }^{1}$

${ }^{1}$ Biochemistry Department, Universidade Federal de Pernambuco, Recife, Pernambuco, Brazil; ${ }^{2}$ Aggeu Magalhães Institute (IAM) - FIOCRUZ/PE , Brazil; ${ }^{3}$ Department of Histology and Embryology, Universidade Federal de Pernambuco, Recife, Pernambuco,Brazil

\section{ABSTRACT}

Plant extraction is a common practice performed in community with the presence of native species with strong population interest. For many Brazilian regions, extractivism acts as a complement of income for the population. The present work aimed to evaluate artisanal liqueurs produced in local communities of the State of Pernambuco in order to observe the antioxidant potentials present during production stages. For this, trials were performed with dpph and abts radicals. All the liqueurs evaluated showed antioxidant potential, with expressive results through the sequestration of the DPPH radical, comprising values of $50 \mathrm{Cl}$ between 0.5 and 2.25 .

Keywords: Caatinga. Antioxidant. Natural products.
*Correspondence to Author: João Victor de Oliveira Alves Biochemistry Department, Universidade Federal de Pernambuco, Recife, Pernambuco, Brazil

\section{How to cite this article:}

João Victor de Oliveira Alves, Francisco Henrique da Silva, João Carlos de Oliveira Pinto, Janderson Weydson Lopes Menezes da Silva, Paloma Maria da Silva, Irivânia Fidelis da Silva Aguiar, Katharina Marques Diniz, Fálba Bernadete Ramos dos Anjos, Márcia Vanusa da Silva. Evaluation of the Antioxidant Potential of Artisanal Liqueurs Produced From Fruits of the Caatinga Biome.Research Journal of Pharmacology and Pharmacy, 2020, 4:8

\section{eScîPub}

eSciPub LLC, Houston, TX USA. Website: https://escipub.com/ 


\section{INTRODUCTION}

Liqueurs and other alcoholic beverages, produced from fruits, flowers and herbs represent one of the most commercialized products among numerous regions. Over the years liquors were used in traditional medicine for presenting therapeutic effects. According to the Guide to American Nutritional Recommendations 2010-2015 and 2015-2020, moderate consumption of alcoholic beverages brings relevant benefits to human health ${ }^{1,2}$.

Produced by hand, through maceration of the raw material with immersion in ethyl alcohol, liqueurs usually present physicochemical characteristics that allow their distinction, with an alcohol content between $5 \%$ and $40 \%{ }^{3}$ and relevant concentrations of phenolic compounds, which are very prevalent in this beverage and are associated with commonly known biological activities, especially the antioxidant potential, which also helps to reduce the natural pro-oxidative activity of alcohol ${ }^{3}$.

Among the most used fruits in the production of liqueurs are cherry, currant, raspberry, and strawberry, among other sources ${ }^{4,5}$. The manufacture of artisanal liqueurs constitutes an integral use of the raw material existing in local communities, adding value to regional fruits and enabling an increase in family income ${ }^{6}$.

In northeastern Brazil, the extraction of non-timber natural products, represented by biological materials obtained from forest ecosystems, natural or artificial, is an important generator of employment and family income, which guarantees the survival of traditional communities, especially in regions with limited industrial resources. In the Caatinga domain, extractive activity contributes to sustainable rural development, whether for food, therapeutic, cosmetic, or decorative purposes. However, due to the peculiar climate and soil characteristics, with long periods of prolonged drought, it is necessary to apply sustainable strategies to face adverse conditions, promote local socioeconomic development and ensure biodiversity conservation ${ }^{7}$.
Even with significant biodiversity, promising bioactive constituents, socioeconomic potential, few studies and information are available about some species predominant in this Caatinga Domain, as well as their final products developed from the raw material extracted. Thus, this work aimed to evaluate the antioxidant potential of artisanal liqueurs produced in local communities, using as raw material fruits of species obtained from the region itself such as Genipa americana, Myrtus communis and Myrciaria tenella..

\section{MATERIAL AND METHODS}

\subsection{Obtaining liquors}

Artisanal liqueurs produced from fruits of the species Genipa americana, Myrtus communis and Myrciaria tenella were acquired directly from the producing communities located in Pernambuco.

\subsection{Preparation of samples}

To investigate the antioxidant potentials, tests were performed with dpph and abts radicals, initially preparing liqueur dilutions in methanol solvent, with initial concentrations of $100 \mu \mathrm{l} / \mathrm{ml}, 50$ $\mu \mathrm{L} / \mathrm{mL}, 25 \mu \mathrm{L} / \mathrm{mL}$. The antioxidant capacity of concentrated liquors was also analyzed.

\subsection{Determination of antioxidant activity by DPPH free radical capture method}

The ability to inhibit free radicals of Genipa Americana (LGA)liqueurs,Myrtus communis (LMC) and Myrciaria tenella (LMT), was determined by the sequestration of the stable radical $\mathrm{DPPH} \bullet$, according to the method of Blois et al. (8) A methothic DPPH solution $(60 \mu \mathrm{M})$ was prepared, adjusted to an initial absorbance between 0.600 and 0.700 , at a wavelength of $517 \mathrm{~nm}$ in a UV-visible SPECTROPHOTOMETER PHOX UV/VIS-DUPLO FEIXE-190 A 1100 -2nm. Then, a reaction mixture was performed by adding $1950 \mu \mathrm{l}$ of DPPH and $50 \mu \mathrm{l}$ of samples of previously diluted liqueurs and the same volume of methanol as control, remaining for 30 minutes and under light. Trolox (Sigma-Aldrich, USA) was used as a standard solution. All analyses were performed in triplicates. At the end, absorbance readings were made and the absorption of 
the samples $(\mathrm{Am})$ correlated with the decay of the absorbance of the control (Ac) resulted in the percentage of free radical sequestration (\%SRL), according to the equation \%SRL=( $A_{c}-$ $\left.A_{m}\right) / A_{c} \times 100$, being $A c=$ absorbance of the control, $A m=$ Absorbance of the sample.

\subsection{Determination of antioxidant activity by the ABTS free radical cation capture method}

For the evaluation of antioxidant potential by the ABTS radical, the methodology previously described by Re et al. (1999) (9) was used. The ABTS radical was prepared from a stock solution $(7 \mathrm{mM})$, adding $88 \mu \mathrm{l}$ of potassium persulfate solution $(144 \mathrm{mM})$, and this mixture was maintained for 16 hours at room temperature and under light. Subsequently, ethyl alcohol was added at the ratio $1: 100$, adjusting the absorbance between 0.70 and $0.80 \mathrm{~nm}$ at a wavelength of $734 \mathrm{~nm}$. In a dark environment, $1 \mathrm{~mL}$ of the ABTS solution was added in quartz buckets and then
$10 \mu \mathrm{l}$ of the liqueur solutions in the different concentrations. Absorbances were measured after 6 minutes of reaction, and as standard solution Trolox was used at concentrations between $2000 \mu \mathrm{M}$ to $100 \mu \mathrm{M}$. All assays were performed in triplicate. The capture activity of the ABTS radical was expressed by inhibition of the ABTS radical in percentage, using the following equation $1 \%==\left(A_{c}-A_{m}\right) / A_{c} \times 100$, being $A c=$ absorbance of the control, $A m=$ Absorbance of the sample.

\section{RESULTS AND DISCUSSION}

\subsection{Antioxidant Activity Assessment}

In order to investigate the antioxidant potentials of $G$. americanaliqueurs, $M$. communis, M. tenellade in vitro assays based on DPPH and ABTS radicals were performed. All liqueur samples evaluated showed more expressive results for the capture of the DPPH radical (Table 1).

Table 1: $(\mu \mathrm{g} / \mathrm{mL})$ of liqueurs of fruits Genipa Americana, Myrtus communis, Myrciaria tenella against antioxidant activity assays by DPPH and ABTS•+ methods.

\begin{tabular}{l|l|l}
\hline Liquors & $\begin{array}{l}\text { DPPH } \\
(\mathrm{IC50} \mu \mathrm{g} / \mathrm{mL})\end{array}$ & $\begin{array}{l}\text { ABTS }(\%) \\
(\mathrm{IC50} \mu \mathrm{g} / \mathrm{mL})\end{array}$ \\
\hline Genipa americana & 2,510 & $>100$ \\
\hline Myrtus communis & 0,555 & $>100$ \\
\hline Myrciaria tenella & 0,548 & $>100$ \\
\hline
\end{tabular}

The results expressed in $\mathrm{Cl}_{50}$ represent the amount of antioxidant compound needed to reduce the initial DPPH concentration by $50 \%$. The liqueur samples of Myrtus communis and Myrciaria tenella showed values of $\mathrm{Cl}_{50}$ very close, with no significant difference between them. However, in relation to the liqueur samples of Genipa americana,the IC50 values of Myrtus communis and Myrciaria tenella were 4.52 and 4.58 respectively, meaning a higher antioxidant activity present in the liqueurs of these two species of the family Myrtaceae. Numerous studies have demonstrated the presence of antioxidant potential in species of the family Myrtaceae, Auricchio et al. in their study demonstrated that $E u$ genia uniflora demosntrou antioxidant potential $34.6 \mu \mathrm{g} / \mathrm{mL}$ of hydroethanolextract results superior to that found in this study. In a study guided by Franco et al. hydroalcoolic extatos of the species Myrcianthes pungens presented results closer to that found in this study, with antioxidant activity of $6.74 \mu \mathrm{g} / \mathrm{mL}$.

Differences in the values demonstrated for species of the same family may be a reflection of climatic conditions to which the plants were exposed, as well as the extraction site of these extracts, such as stem, leaves and roots. In the 
study guided by Franco et al. (11) the extracts obtained were directly from flours from the roots of the species M. pugens. These and other factors reflect directly on the secondary metabolic pathway of plants, altering concentrations of the major compounds responsible for the numerous biological activities intrinsic to the plant.

The DPPH test is one of the most used indirect methods to determine the antioxidant potential of molecules when hijacking the DPPH radical. The interaction of antioxidant active with DPPH will depend on its structural conformations, another important factor for the determination of the antioxidant potential of substances is its solublization character. The DPPH radical is a radical acquired in the free form, without the requirement of prior preparation, as occurs in the technique by the ABTS radical, which in turn generated by enzymatic or chemical reactions.

The ABTS radical can be prepared in organic or aqueous media, a characteristic that confers applicity in compounds of lipophilic or hydrophilic characteristics, while DPPH can only be solubilized in organic solvents, specifically alcoholic (12)

Due to these intrinsic characteristics of both methodologies, it can be explained the significant difference present in the IC50 of the methodologies employed, since the DPPH radical presents a greater interaction with the liqueurs produced from an immersion in ethanol.

\section{CONCLUSION}

Thus, for the assays used in this study, the methanolelic liqueurs produced from fruits of the species Genipa Americana, Myrtus communis, Myrciaria tenella showed antioxidant potential, and expressive results were observed through the sequestration of the DPPH radical.

\section{REFERENCES}

1. Department of Agricuture $U$, Department of Health U, Services H. Dietary Guidelines for Anericans 2010 - DietaryGuidelines2010.pdf. 2010; Available from: www.dietaryguidelines.gov

2. Lonie S, Farley D. Dietary guidelines for americans 2015-2020. 2009;20(2):1-8. Available from: http://health.gov/dietaryguidelines/2015/guidelines /.

3. Sokół-Łetowska A, Kucharska AZ, Szumny A, Winska K, Nawirska-Olszanska A. Phenolic composition stability and antioxidant activity of sour cherry liqueurs. Molecules. 2018;23(9).

4. Stampar F, Solar A, Hudina M, Veberic R, Colaric M. Traditional walnut liqueur - Cocktail of phenolics. Food Chem. 2006;95(4):627-31.

5. Senica M, Stampar F, Veberic R, MikulicPetkovsek M. Transition of phenolics and cyanogenic glycosides from apricot and cherry fruit kernels into liqueur. Food Chem [Internet]. Elsevier Ltd; 2016;203:483-90. Available from: http://dx.doi.org/10.1016/j.foodchem.2016.02.110

6. Lynch AG, Mulvihill DM. Effect of sodium caseinate on the stability of cream liqueurs. Int $J$ Dairy Technol. 1997;50(1):1-7.

7. BRASIL. Ministério do Meio Ambiente. Relatório de Monitoramento de esmatamento do Bioma Caatinga, 2009. Disponível em: <http://www.mma.gov.br/>. Acesso em: Abril/2019.

8. BLOIS, Marsden S. Antioxidant determinations by the use of a stable free radical. Nature, v. 181, n. 4617, p. 1199, 1958.

9. Re R, Pellegrini N, Proteggenete A, Pannala A, Yang M, Rice-Evans C. Trolox ASSAY. Int Antioxid Res Centre, Guy's, King's St Thomas' Sch Biomed Sci Kings Coll Campus, London SE1 9RT, UK [Internet]. 1999;26(98):Free Radical Biology \& Medicine, Vol. 26, Nos. 9/1.

10. Negri MLS, Possamai JC, Nakashima T. Atividade antioxidante das folhas de espinheirasanta - Maytenus ilicifolia Mart. ex Reiss., secas em diferentes temperaturas. Brazilian $\mathrm{J}$ Pharmacogn. 2009;19(2 B):553-6.

11. FRANCO, Flaviane Borges et al. TRIAGEM FITOQUÍMICA E ATIVIDADE ANTIOXIDANTE DE Arctium lappa Linne E Myrcianthes pungens. Revista Científica da UNIFENAS, v. 1, n. 1, 2019.

12. TEIXEIRA, L. J. Q. et al. Tecnologia, composição e processamento de licores. Enciclopédia Biosfera, Centro Científico Conhecer-Goiânia, v. 7, n. 12, p. 2, 2011. 